\title{
Antidepressant-like effect of lead in adult mice
}

M. Mantovani, A.S. Matteussi and A.L.S. Rodrigues
Departamento de Bioquímica, Centro de Ciências Biológicas,

Universidade Federal de Santa Catarina, Florianópolis, SC, Brasil

\begin{abstract}
Correspondence
A.L.S. Rodrigues

Departamento de Bioquímica

CCB, UFSC

88040-900 Florianópolis, SC

Brasil

Fax: + 55-48-331-9672

E-mail: analucia@mbox1.ufsc.br

Presented at the XIV Annual Meeting of the Federação de Sociedades de Biologia Experimental, Caxambu, MG, Brasil, August 25-28, 1999.

$M$. Mantovani is the recipient of a CNPq fellowship (No. 520871/97-9).
\end{abstract}

Received April 13, 1999 Accepted October 13, 1999

\section{Abstract}

It has been reported that lead can cause behavioral impairment by inhibiting the N-methyl-D-aspartate (NMDA) receptor complex. MK801, a noncompetitive NMDA receptor antagonist, exhibits an antidepressant-like action in the forced swimming test. The purpose of the present study was to determine whether subacute lead exposure in adult male Swiss mice weighing 30-35 g causes an antidepressant-like action in a forced swimming test. Mice were injected intraperitoneally (ip) with $10 \mathrm{mg} / \mathrm{kg}$ lead acetate or saline daily for 7 consecutive days. Twenty-four hours after the last treatment, the saline and lead-treated mice received an injection of MK-801 $(0.01 \mathrm{mg} / \mathrm{kg}$, ip $)$ or saline and were tested in forced swimming and in open-field tests. Immobility time was similarly reduced in the saline-MK- $801, \mathrm{~Pb}$-saline and $\mathrm{Pb}$ MK-801 groups compared to the saline-saline group (mean \pm SEM; $197.3 \pm 18.5,193.5 \pm 15.8,191.3 \pm 12.3$ and $264.0 \pm 14.4 \mathrm{~s}$, respectively; $\mathrm{N}=9$ ). These data indicate that lead may exert its effect on the forced swimming test by directly or indirectly inhibiting the NMDA receptor complex. Lead treatment caused no deficit in memory of habituation and did not affect locomotor activity in an open-field $(\mathrm{N}=14)$. However, mice that received MK-801 after lead exhibited a deficit in habituation $(22 \%$ reduction in rearing responses between session 3 and $1 ; \mathrm{N}=14$ ) as compared to control (41\% reduction in rearing responses; $\mathrm{N}=15$ ), further suggesting that lead may have affected the NMDA receptor activity. Forced-swim immobility in a basin in two daily consecutive sessions was also significantly decreased by lead exposure (mean \pm SEM; day $1=10.6 \pm 3.2$, day $2=$ $19.6 \pm 3.6 ; \mathrm{N}=16$ ) as compared to control (day $1=18.4 \pm 3.8$, day 2 $=34.0 \pm 3.7 ; \mathrm{N}=17$ ), whereas the number of crossings was not affected by lead treatment, further indicating a specific antidepressant-like action of lead.
Lead $(\mathrm{Pb})$ is an environmental pollutant ubiquitous in nature, that has long been known to affect the central nervous system (CNS), exerting neurotoxic effects, especially producing cognitive deficits in children and young experimental animals (1). Adults are more resistant to the effects of lead on the
Key words

- Lead acetate

- Forced swimming test

- Depression

- Open-field
CNS, but some studies have reported cognitive impairment and changes in mood and affect following lead exposure in adult animals $(2,3)$.

The mechanisms underlying the behavioral alterations caused by lead seem to be dependent, at least in part, on inhibition of 
the N-methyl-D-aspartate (NMDA) receptor complex $(1,4,5)$. Lead exposure has been reported to inhibit the binding of the noncompetitive NMDA receptor complex antagonist MK-801 to its site within the ion channel, which suggests that lead inhibits the NMDA receptor-ion channel activation (4-6). Since it has recently been reported that some NMDA receptor antagonists have antidepressant-like effects (7), the present study was conducted to investigate whether subacute lead acetate exposure $(10 \mathrm{mg} / \mathrm{kg}$, ip, for 7 days) has an antidepressant action on adult mice in the forced swimming test (FST). This test is one of the most frequent behavioral tests used to measure potential antidepressant activity (8). The development of immobility when mice or rats are placed in an inescapable cylinder of water is thought to represent a failure of persistance in escape-directed behavior or the development of passivity in response to stress. The FST measures the ability of antidepressants to reduce the occurrence of immobility after exposure to swimming stress. The effect of the lead-exposure regimen under study on the locomotor activity and on memory of habituation in an open-field was also assessed in the present study.

Male Swiss mice weighing 30-35 g (7090 days of age) were used. Animals were maintained at $22-27^{\circ} \mathrm{C}$ with free access to water and food. All observations were made between 10:00 and 17:00 h, with each animal used only once. Lead acetate was dissolved in saline $(1 \mathrm{mg} / \mathrm{ml})$ and administered once a day for 7 consecutive days by the intraperitoneal route to mice $(10 \mathrm{mg} / \mathrm{kg})$ in a volume of $10 \mathrm{ml} / \mathrm{kg}$ body weight. Control animals received saline. Each group of animals received an injection of saline or MK$801,0.01 \mathrm{mg} / \mathrm{kg}, i p, 24 \mathrm{~h}$ after the end of treatment. The challenge with MK-801 after $\mathrm{Pb}$ treatment was based on reports that exposure to lead inhibits the binding of MK-801 $(5,6)$ and thus might affect the sensitivity to the behavioral effects of MK-801 in the FST.
Thirty minutes after the injection of MK-801 or saline, forced swimming and open-field tests were carried out by the methods of Porsolt et al. (8) and Rodrigues et al. (9), respectively. For the FST, the mice were forced to swim individually in an open cylindrical container $(10 \mathrm{~cm}$ in diameter, and 25 $\mathrm{cm}$ high), containing $19 \mathrm{~cm}$ of water at $25 \pm$ $1^{\circ} \mathrm{C}$ and the duration of immobility during a 6-min test was scored. For the open-field test, mouse behavior was assessed in three identical sessions (6 min of duration) on consecutive days. The numbers of squares crossed with all paws (crossings) and of standing on the hind legs (rearings) were scored in the sessions. The number of crossings indicated locomotor activity and the decrease in the number of rearings between sessions was taken to be a measure of habituation $(9,10)$.

One-way ANOVA revealed that there was a significant effect of treatment on the forced-swim immobility (characterized by increasingly frequent bouts of complete motionlessness in an FST, i.e., behavioral despair $(\mathrm{F}(3,32)=4.47, \mathrm{P}<0.01)$. Post-hoc Duncan comparisons showed that immobility was reduced by subacute exposure to lead in a way similar to the result produced by the acute injection of the NMDA receptor antagonist MK-801 (0.01 mg/kg, ip). No synergistic or additive effect on immobility was observed in mice exposed to lead acetate for 7 days and subsequently (8th day) injected with MK-801, since the Pb-MK-801 group did not differ from the $\mathrm{Pb}$-group or from the MK-801 group (Figure 1). Hence, the Pb-sal, sal-MK-801 and Pb-MK-801 groups showed reduced immobility upon exposure to swimming stress similar to that obtained with antidepressant drugs (8). Since MK-801 preferentially binds to the activated NMDA receptor complex (11), the absence of a synergistic or additive effect in mice receiving $\mathrm{Pb}$ and MK-801 was probably due to the fact that lead exposure decreased the NMDA receptor activation. MK-801 subsensitivity 
following lead exposure has been demonstrated previously (12).

In order to exclude the possibility that lead and/or MK-801 reduced immobility by a stimulant action, such as obtained with amphetamine (8), mice exposed to lead (10 $\mathrm{mg} / \mathrm{kg}$, ip, for 7 days) and/or MK-801 (0.01 $\mathrm{mg} / \mathrm{kg}$, ip) were assessed for ability to increase motor activity in an open-field. Twoway ANOVA for repeated measures applied to crossing responses in the open-field (Table 1) revealed a significant effect of sessions $(\mathrm{F}(2,110)=55.5, \mathrm{P}<0.01)$. No significant effects of treatment $(\mathrm{F}(3,55)=0.41, \mathrm{P}>0.05)$ or of treatment $\mathrm{x}$ session interaction were observed $(\mathrm{F}(6,110)=1.66, \mathrm{P}>0.05)$. Post$h o c$ analysis showed that all groups of mice presented a significant decrease in crossing scores along sessions, although the difference in the crossing scores between session 3 and session 1 was lower in the Pb-MK-801 group as compared to the other groups. Moreover, no differences between groups were demonstrated in the first session. This result indicates that the lead- and MK-801-induced decrease in immobility in the FST (Figure 1) was not due to an increase in ambulation elicited by the metal and/or by MK- 801 . The absence of an effect of the MK-801 dose used in the present study on locomotor activity in mice had been previously demonstrated (13).
Two-way ANOVA for repeated measures of rearing responses in the open-field (Table 1) showed a significant main effect of session $(\mathrm{F}(2,110)=41.7, \mathrm{P}<0.01)$ and of lead treatment $\mathrm{x}$ sessions interaction $(\mathrm{F}(6,110)=2.40, \mathrm{P}<0.05)$. No significant effect of treatment was observed $(\mathrm{F}(3,55)=$ 1.27, P>0.05). Post-hoc analysis by Duncan's test showed that all groups except Pb-MK801 showed a significant reduction in number of rearing responses during the third session as compared to the first session. This indicates that all except Pb-MK-801 had memory of habituation. These results show that the lead-exposure regimen used in the present study did not cause impairment of memory of habituation per se, in contrast to the result obtained by us with young rats

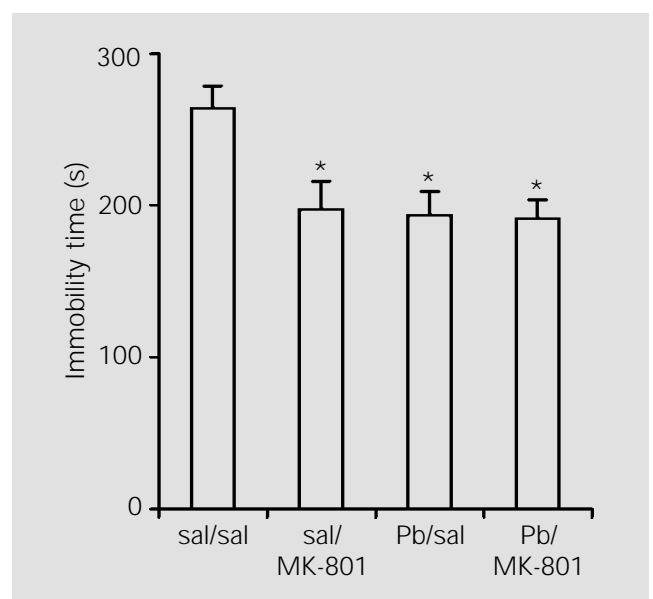

Figure 1 - Effect of lead and/or MK-801 treatment on immobility in FST. Data are reported as mean \pm SEM. Mice were treated with saline (sal) or lead acetate $(\mathrm{Pb}, 10 \mathrm{mg} / \mathrm{kg}$, ip) for 7 consecutive days. Twenty-four hours after the treatment mice received an ip injection of saline or MK$801(0.01 \mathrm{mg} / \mathrm{kg})$. FST was carried out $30 \mathrm{~min}$ after this injection. The session lasted $6 \mathrm{~min}$. $* \mathrm{P}<0.01$ compared to sal/sal group (Duncan test).
Table 1 - Effect of lead and/or MK-801 treatment on crossing and rearing responses in an open-field.

Data are reported as mean \pm SEM. Mice were treated with saline or lead acetate $(\mathrm{Pb})(10 \mathrm{mg} / \mathrm{kg}$, ip) for 7 consecutive days. Twenty-four hours after the end of treatment mice received an ip injection of saline or MK$801(0.01 \mathrm{mg} / \mathrm{kg})$. The first session in the open-field was carried out $30 \mathrm{~min}$ after this injection. Mice were subjected to three identical sessions on consecutive days. Each session lasted 6 min. *P<0.05 when the third session is compared with the first session for the same group (Duncan test).

\begin{tabular}{|c|c|c|c|c|c|c|c|}
\hline \multirow[t]{2}{*}{ Treatment } & \multirow[b]{2}{*}{$\mathrm{N}$} & \multicolumn{3}{|c|}{ Number of rearings } & \multicolumn{3}{|c|}{ Number of crossings } \\
\hline & & Session 1 & Session 2 & Session 3 & Session 1 & Session 2 & Session 3 \\
\hline Saline/saline & 15 & $55.3 \pm 4.0$ & $42.6 \pm 5.9$ & $32.7 \pm 6.2^{*}$ & $98.1 \pm 5.6$ & $82.5 \pm 8.4$ & $51.6 \pm 8.5^{*}$ \\
\hline Saline/MK-801 & 15 & $53.8 \pm 4.1$ & $48.0 \pm 3.8$ & $24.8 \pm 3.3^{*}$ & $89.4 \pm 5.1$ & $80.9 \pm 8.1$ & $52.4 \pm 5.0^{*}$ \\
\hline $\mathrm{Pb} /$ saline & 14 & $50.3 \pm 4.1$ & $34.4 \pm 3.2$ & $22.2 \pm 2.9 *$ & $93.5 \pm 6.7$ & $67.1 \pm 4.5$ & $48.1 \pm 4.0^{*}$ \\
\hline Pb/MK-801 & 14 & $41.4 \pm 2.5$ & $41.3 \pm 4.6$ & $32.2 \pm 4.5$ & $83.9 \pm 5.1$ & $75.1 \pm 6.5$ & $61.8 \pm 7.5^{*}$ \\
\hline
\end{tabular}


exposed to lead (9). This was probably due to the fact that adult rodents are more resistant to the effects of lead on memory than young rodents $(1,2)$. Memory of habituation in an open-field is dependent on the hippocampus and on the activation of the NMDA receptor (14). Inhibition of the NMDA receptor by lead is more prominent in young than in mature cultured hippocampal neurons (15), possibly explaining why cognitive deficits caused by lead are more prevalent in young animals. The age dependence of the inhibitory effect of lead may represent different sensitivities to lead of different subtypes of NMDA receptors expressed at different times of development (15). However, the result obtained with the Pb-MK-801 interaction suggests that, under the conditions used, lead may have somewhat affected the NMDA receptor complex. The mechanism responsible for this effect still remains to be clarified.

An independent group of mice treated with $\mathrm{Pb}$ or saline for 7 consecutive days was tested in a swimming test as described by Stewart et al. (16). Briefly, the water basin was a 54 x 54 x $31 \mathrm{~cm}$ white fiberglass box with a floor divided into a grid of $36.9 \times 9$ squares. The basin was filled with water at $25 \pm 1^{\circ} \mathrm{C}$ to a depth of $25 \mathrm{~cm}$. A mouse was placed in the center of the basin and both immobility time and number of squares crossed over a 2-min period were recorded daily for two days. The evaluation of the effects of lead on the FST in a basin confirms the reduction of immobility caused by lead in the cylindrical container and permits us to verify the crossing scores in a situation of swimming stress similar to the one existing in forced swimming in the cylinder. Since lead might affect locomotion mainly under stress conditions (17), the antidepressantlike effect of lead observed in the forced swimming in the cylinder may have been due to hyperactivity caused by lead in a swimming stress condition that could not have been detected in the open-field. Hence, the main rationale for the choice of the FST in a basin, in addition to the more frequently used FST in a cylinder, was to preclude the possibility that lead caused a reduction in immobility in the FST by causing an increase in motor activity in a swimming stress condition.

The crossing responses of mice treated with saline or lead acetate $(10 \mathrm{mg} / \mathrm{kg}$, ip, for seven consecutive days) and tested in an FST in a basin for two consecutive days were as follows: day $1=157.0 \pm 8.1$, day $2=140.4$ $\pm 8.9 v s$ day $1=164.5 \pm 8.1$, day $2=141.1 \pm$ 9.4 (mean \pm SEM; $\mathrm{N}=17$ and 16, respectively). Two-way ANOVA for repeated measures of crossings showed no differences for treatment $(\mathrm{F}(1,31)=0.14, \mathrm{P}>0.05)$ and no interaction between session and treatment $(\mathrm{F}(1,31)=0.40, \mathrm{P}>0.05)$. Only a main significant effect of session was observed $(\mathrm{F}(1,31)=14.3, \mathrm{P}<0.01)$, since in the second session the number of crossings in both groups decreased as compared to the first session.

Immobility data in forced swimming in a basin (two consecutive days) of mice treated with saline or lead acetate $(10 \mathrm{mg} / \mathrm{kg}$, ip, for seven consecutive days) were as follows: day $1=18.4 \pm 3.8$, day $2=34.0 \pm 3.7 v s$ day $1=10.6 \pm 3.2$, day $2=19.6 \pm 3.6$ (mean (s) \pm SEM; $\mathrm{N}=17$ and 16, respectively). Twoway ANOVA for repeated measures of immobility showed a significant main effect of both treatment $(\mathrm{F}(1,31)=5.9, \mathrm{P}<0.05)$ and session $(\mathrm{F}(1,31)=28.9, \mathrm{P}<0.01)$. No significant effect of treatment $x$ session interaction was observed $(\mathrm{F}(1,31)=2.12, \mathrm{P}>0.05)$.

The present results showing a lead-induced decrease in immobility time as well as an absence of lead effect on locomotor activity in FST in a basin agree with the results obtained by Stewart et al. $(16,18)$ in leadexposed mice. The absence of a lead-induced hyperactivity upon this condition does not support the notion that changes in locomotor activity in lead-exposed rodents are manifested most markedly in aversive or 
stressful provoking situations (17). The apparently conflicting reports may be due to the dose and regimen of lead exposure, age and the animal specimen employed.

The absence of a lead effect on locomotor activity in the open-field and in the FST in a basin confirms our previous conclusion that lead caused a specific antidepressantlike effect in the FST. It is interesting to note that immobility increased as a function of session both in the control group and in the lead-exposed group, in contrast to a previous study (18). This behavior has been considered as behavioral depression and may suggest learned helplessness $(18,19)$. However, even in the second session the immobility was significantly lower in the $\mathrm{Pb}$ group than in the control group.

The precise mechanism underlying the antidepressant-like action of lead remains to be clarified. Lead is known to have multiple effects, certainly due to its interaction with different molecular targets, which are expressed in different concentration range. Direct blockade of NMDA receptors occurs at relatively high concentrations (4), especially in mature neurons. However, a recent report has shown that very low concentrations of lead reduce glutamatergic transmission by decreasing glutamate release (20). Thus, some of the impairment may result either from a direct blockade of the NMDA receptors or from the indirect decrease of the NMDA receptor activity via depression of glutamate release. However, such hypotheses should be further investigated in the lead exposure regimen used in the present study. Moreover, we cannot exclude the possibility that lead may also exert its antidepressant-like action by affecting other neurotransmitter systems. Thus, while any generalizations to human populations should be cautioned, these results suggest the need for further research.

\section{Acknowledgments}

The authors thank E. Grimm for correcting the English text.

\section{References}

1. Cory-Slechta D (1995). Relationships between lead-induced learning impairments and changes in dopaminergic, cholinergic, and glutamatergic neurotransmitter system functions. Annual Review of Pharmacology and Toxicology, 35: 391-415.

2. Davis J M, Otto DA, Weil DE \& Grant LD (1990). The comparative developmental neurotoxicity of lead in humans and animals. Neurotoxicology and Teratology, 12: 215-229.

3. Silbergeld EK (1992). Mechanisms of lead neurotoxicity, or looking beyond the lamppost. FASEB J ournal, 6: 3201-3206.

4. Alkondon $M$, Costa ACS, Radhakrishnan V, Aronstam RS \& Albuquerque EX (1990). Selective blockade of NMDA-activated channel currents may be implicated in learning deficits caused by lead. FEBS Letters, 261: 124-130.

5. Cory-Slechta DA, Garcia-Osuna M \& Greenamyre JT (1997). Lead-induced changes in NMDA receptor complex bind- ing: correlations with learning accuracy and with sensitivity to learning impairments caused by MK-801 and NMDA administration. Behavioural Brain Research, 85: 161-174.

6. Guilarte TR, Miceli RC \& J ett DA (1994). Neurochemical aspects of hippocampal and cortical $\mathrm{Pb}^{2+}$ neurotoxicity. Neurotoxicology, 15: 459-466.

7. Trullas R \& Skolnick P (1990). Functional antagonists at the NMDA receptor complex exhibit antidepressant actions. European J oumal of Pharmacology, 185: 1-10.

8. Porsolt RD, Bertin A \& J alfre M (1977). Behavioral despair in mice: a primary screening test for antidepressants. Archives Internationales de Pharmacodynamie et de Therapie, 229: 327-336.

9. Rodrigues ALS, Rocha J BT, Mello CF \& Souza DO (1996). Effect of perinatal lead exposure on rat behaviour in open-field and two-way avoidance tasks. Pharmacology and Toxicology, 79: 150-156.
10. Netto CA, Dias RD \& Izquierdo I (1986). Training in an open-field: Simultaneous learning of habituation and of a water finding task, and differential effect of posttraining naloxone, beta-endorphin, leu-enkephalin and electroconvulsive shock on the retention of both tasks. Psychoneuroendocrinology, 11: 437-446.

11. J avitt DC \& Zukin SR (1989). Bi-exponential kinetics of $\left[{ }^{3} \mathrm{H}\right] \mathrm{MK}-801$ binding: evidence for access to closed and open $\mathrm{N}$ methyl-D-aspartate receptor channels. Molecular Pharmacology, 35: 387-393.

12. Cory-Slechta DA (1995). MK-801 subsensitivity following postweaning lead exposure. Neurotoxicology, 16: 83-96.

13. Shen EH \& Philliips TJ (1998). MK-801 potentiates ethanol's effects on locomotor activity in mice. Pharmacology, Biochemistry and Behavior, 59: 135-143.

14. Izquierdo I \& Medina J H (1993). Role of amygdala, hippocampus and entorhinal cortex in memory consolidation and ex- 
pression. Brazilian J oumal of Medical and Biological Research, 26: 573-589.

15. Ujihara $H \&$ Albuquerque EX (1992). Developmental change of the inhibition by lead of the NMDA-activated currents in cultured hippocampal neurons. J ournal of Pharmacology and Experimental Therapeutics, 263: 868-875.

16. Stewart PW, Burright RG \& Donovick PJ (1995). DMSA chelation during co-exposure to lead: increased locomotor activity in lead-exposed mice but not controls.
Physiology and Behavior, 57: 863-867.

17. Barret J \& Livesey PJ (1985). Low level lead effects on activity under varying stress conditions in the developing rat. Pharmacology, Biochemistry and Behavior, 22: 107-118.

18. Stewart PW, Blaine C, Cohen M, Burright RG \& Donovick PJ (1996). Acute and longer term effects of meso-2,3 dimercaptosuccinic acid (DMSA) on the behavior of lead-exposed and control mice. Physiology and Behavior, 59: 849-855.
19. Porsolt RD, Anton G, Blavat $N$ \& J alfre $M$ (1978). Behavioural despair in rats: A new model sensitive to antidepressant treatments. European J ournal of Pharmacology, 47: 379-391.

20. Braga MF, Pereira EF \& Albuquerque EX (1999). Nanomolar concentrations of lead inhibit glutamatergic and GABAergic transmission in hippocampal neurons. Brain Research, 826: 22-34. 